This item was submitted to Loughborough's Research Repository by the author.

Items in Figshare are protected by copyright, with all rights reserved, unless otherwise indicated.

\title{
Patterns of instability: moves within the care system, their reasons, contexts and consequences
}

\section{PLEASE CITE THE PUBLISHED VERSION}

http://dx.doi.org/10.1016/j.childyouth.2009.07.009

\section{PUBLISHER}

(C) Elsevier Ltd.

\section{VERSION}

AM (Accepted Manuscript)

\section{PUBLISHER STATEMENT}

This work is made available according to the conditions of the Creative Commons Attribution-NonCommercialNoDerivatives 4.0 International (CC BY-NC-ND 4.0) licence. Full details of this licence are available at: https://creativecommons.org/licenses/by-nc-nd/4.0/

\section{LICENCE}

CC BY-NC-ND 4.0

\section{REPOSITORY RECORD}

Ward, Harriet. 2019. "Patterns of Instability: Moves Within the Care System, Their Reasons, Contexts and Consequences". figshare. https://hdl. handle.net/2134/15869. 


\section{Patterns of Instability: moves within the English care system, their reasons, contexts and consequences}

Harriet Ward, Centre for Child and Family Research, Loughborough University, Leicestershire, UK

Email address: h.ward@lboro.ac.uk

Phone: $+44(0) 1509223672$

Mailing address: Centre for Child and Family Research, Department of Social

Sciences, Loughborough University, Leicestershire, UK, LE11 3TU

Running title: Patterns of instability in care

Address for reprints: as above

Acknowledgements: The study was funded by the Department of Health and the Department for Children, Schools and Families, England. 


\section{Abstract}

The unstable nature of placements impacts on children's education, health and emotional development and contributes to the poor outcomes of care. The present study examined the moves of 242 long-stay children for a minimum of 3.5 years after they entered the care of six English local authorities using quantitative data extracted from case files and qualitative data from interviews with children and young people. During the study period 965 placements were made and 843 ended. The median length of placements in foster family care was four months and 3.5 months in residential care, and did not substantially increase until the third year of the care episode. While the numbers of placements differed according to children's ages and attributes, even very young children with no additional support needs experienced frequent moves. Instability in care replicated children's experiences within their birth families and reinforced perceptions of transience. While some placements broke down, the majority of moves were planned transitions embedded in the case management process. These may be a response to inadequate resources, but they also reflect how social workers and the courts struggled to acknowledge that some parents would not be able to provide adequate care within a child's timescale.

Key words: out of home care; placements; foster care; residential care; placement instability; placement disruption 


\section{Introduction}

Evidence that children and young people placed in out of home care often fail to achieve 'satisfactory wellbeing in adulthood' is a matter of concern in most Western societies (Stein and Munro, 2008). In England, the chances of children and young people looked after by local authorities achieving the equivalent of high school graduation are four times less than those of their peers; they are also three times as likely to be unemployed three months after leaving school than their peers and twice as likely to be cautioned or convicted of criminal offences (Department for Children, Schools and Families, 2008a). Data such as these are often presented as evidence of a failing system (see Sergeant, 2006), although there are many, complex factors which contribute to such disappointing outcomes, only a few of which are attributable to children's social care (Ward, 2008). One factor, however, which is likely to impact on the life trajectories of children in care is the unstable nature of placements, again a common problem, both in the United Kingdom, North America and Australia and in much of Europe (Stein and Munro, 2008; Unrau, 2007). English children move home on average three times before reaching adulthood (Moyers and Mason, 1995), whereas it is not unusual for those in the care system to experience the equivalent level of change in the course of a year (Department for Children Schools and Families, 2008b).

While some moves are of positive benefit to the children and young people concerned, others can be damaging to their life chances. Instability is one of the major reasons why welfare outcomes for children in out-of-home care are often so 
disappointing, for constant change can have a major impact not only on children and young people's patterns of attachment and emotional wellbeing (Ward, Munro and Dearden, 2006) and their sense of self-esteem and identity (Skuse and Ward, 2003; Unrau, Seita and Putney, 2008) but also on their access to education (Social Exclusion Unit, 2003 ) and health care (Ward et al., 2002).

This paper presents findings from a cluster of studies commissioned by the English government (Department for Children, Schools and Families) to explore how welfare outcomes for children placed in out of home care might be improved. It discusses the extent of instability experienced by these children, some of the reasons for it, its consequences and some issues that might be addressed to provide greater stability.

\section{Methodology}

All children and young people who came into the care of six English local authorities between 1 April 1996 and 31 March 1997 and who remained looked after for at least twelve months were eligible for selection to an intensive, longitudinal study. Two hundred and forty two children could be identified who fit the study criteria and extensive quantitative data were collected from case files on their needs, placements and the services they received at entry to care and at regular intervals until September 2000 (a minimum of 3.5 years post entry). All placements were counted, regardless of their duration. Quantitative data were complemented with qualitative data from case files and interviews with a sub-sample of those children and young people who left the care of the authorities during the course of the study and who were followed until 2002 (Skuse and Ward, 2003). A subset of additional, more 
detailed, data were collected from case files and interviews with carers, professionals and birth parents concerning the needs and experiences of the 42 children in the sample who entered the care of the authorities before their first birthdays. These children were followed from birth until 2004, when they were aged six or seven (Ward, Munro and Dearden, 2006). The sample is undoubtedly incomplete, and indeed the first findings concerned the difficulties faced by the participating authorities in identifying children who met the criteria (Skuse, Macdonald and Ward, 2000); nevertheless there was no evidence of any particular bias, and the database provides a rich source of information that illuminates the extent of instability in the English care system and the reasons for it.

\section{Findings}

\section{The children}

Figure One gives a picture of the ages of sample children at entry to care or accommodation. This was a group of children and young people who stayed long in care, and it is noteworthy that very young children were substantially overrepresented. There were twice as many babies admitted before their first birthday as children in any other age group, hence the complementary study that gave particular attention to their needs and circumstances (Ward, Munro and Dearden, 2006). While babies were over-represented, the sample as a whole included a disproportionate number of children who were admitted before they were five (98: 41\%). At the other end of the age spectrum, there were 19 fifteen year olds and 17 fourteen year olds, but there were not conspicuously more young people in these age groups than in others. In fact teenagers (13-15 year olds) made up $20 \%$ of the total sample, while sixteen year olds were conspicuous by their absence. Although substantially more 
teenagers come into the English care system than other age groups, they do not remain looked after long enough to appear over-represented in a sample such as this.

\section{INSERT FIGURE 1 HERE}

A hundred and eight (45\%) of these long-stay children and young people were girls and slightly more (134:55\%) were boys. Nearly three quarters of the children (172:73\%) were identified as white British. Very few children came from black African, Asian, black Caribbean or Irish families. There were, however, a high percentage of children of dual or multiple heritage (49:21\%), a point noted in other studies (Rowe, Hundleby and Garnett, 1989; Packman and Hall, 1998).

\section{Needs}

This long-stay sample of children and young people in the English care system displayed evidence of extensive support needs, a finding that reflects those of other recent studies (see Ward, Holmes and Soper, 2008; Meltzer et al, 2003). At entry, 124 (51\%) were displaying emotional or behavioural difficulties sufficient to be regarded by practitioners as 'a cause of concern to themselves or current carers' (see Sempik, Ward and Darker, 2008); 19 (8\% of those aged 10 and over) had been cautioned or convicted of an offence (see Darker, Ward and Caulfield, 2008); 83 (34\%) were identified by social workers as having a physical or learning disability or learning difficulty; only 95 (39\%) showed no evidence of additional needs. In a study of a different cohort the research team has shown how additional support needs such as those above, singly and in combination, affect both the types of placement offered 
and their stability, leading to significant differences in the costs and experiences of children who fall into a range of different needs groups (Ward, Holmes, and Soper, 2008; Ward and Holmes, 2008). Using the categorisation developed in this earlier study, the children in the current sample could be grouped as shown in Table 1.

\section{INSERT TABLE 1 HERE}

\section{Numbers of placements}

Only 46 children (19\%) stayed in the same placement throughout the study (3.5 years), although 100 (41\%) had one or two placements. However $53(22 \%)$ had more than five placements and ten had ten or more, including one young person who had 29. The figures are presented in Table 2.

\section{INSERT TABLE 2 HERE}

As Table 2 also shows, the number of placements differed according to children's ages $^{1}$. More specifically, children and young people aged ten and over had significantly more placements than those aged $0-4^{2}$ or $5-9^{3}$. However, no significant differences were found in the numbers of placements experienced by the two younger 0-4 and 5-9 age groups ${ }^{4}$. While the greater numbers of placements for older children and young people may be related to the higher prevalence of emotional or

\footnotetext{
${ }^{1} \mathrm{X}^{2}(8, \mathrm{n}=241)=32.224, \mathrm{p}<0.01$

${ }^{2} X^{2}(4, n=176)=25.297, p<0.01$

${ }^{3} X^{2}(4, n=143)=13.139, p=.011$

${ }^{4} X^{2}(4,163)=3.263, p=.515$
} 
behavioural difficulties and offending behaviour in this age group, this is only part of the picture: it is noteworthy that 17 (17\%) 0-4 year olds and $12(19 \%) 5-9$ year olds experienced more than five placements during this time period, and that $16(55 \%)$ of these were children and young people who showed no evidence of additional support needs.

\section{Length of placements}

The corollary of frequent movement is that there were a high number of relatively short placements. The sample of 242 children and young people had 965 placements between them in the four years of the study. The mean length of all placements was 298 days, but there was extensive variation (standard deviation=377.2) and so the median (126 days) gives a more useful picture; $17 \%$ of all placements lasted less than three months, $57 \%$ less than six months, and only $29 \%$ of all placements lasted for more than a year. The median length of placements in the two commonest types, foster care with others and residential units, was four months and 3.5 months respectively, only a little longer than a school term.

\section{Placement changes in each year of the care episode}

More than half (52\%) of the placements made in the first twelve months of the children's care episodes lasted for six months or less, with a median of four months. In the second year, however, a similar pattern emerged, with $56 \%$ of new placements lasting for six months or less, and a median of three months. It was not until the third year after entry to care that there was some evidence of increased permanence, but even then $42 \%$ of placements made during this period lasted for six months or less, and the median had only increased to seven months. All the 122 children who were 
still in the care of the authorities at the end of the study had been looked after for at least 3.5 years; of these children, just over half (65: 53\%) had been in their final placements for two or more years, and 30 (25\%) for less than a year.

While these figures provide a broad overview, they do not explain why children move so frequently, which children are likely to move or how unstable placements relate to other areas of their lives. The following paragraphs explore these issues further.

\section{Reasons for placement changes}

Of the 965 placements made in the course of the study, 843 ended, and 122 were still extant at its conclusion; 125 of these placement endings represented managed moves out of the care system, as children returned home to parents or relatives or moved on to adoption or independent living. However the vast majority (718: 85\%) represented moves within the care system. There was missing or inadequate data on 18 of these. Table 3 gives the reasons why the remaining 700 placements ended, categorised as occurring on the initiative of the authority, the carers or the child.

\section{INSERT TABLE 3 HERE}

\section{Planned transitions within the case management process}

The majority (378:54\%) of moves were initiated by the local authorities. A relatively small number (76:11\%) occurred because the placement ceased to be available, either because it had always been envisaged as time-limited (47:7\%) or because a residential unit closed down or a foster carer retired or died (29:4\%). A far greater proportion occurred as 'planned transitions', as part of the case management 
process. This was the single most common reason for placement endings, accounting for $302(43 \%)$ of all moves within care.

\section{INSERT TABLE 4 HERE}

Planned transitions were the single most common reason not only for ending first placements, but also for ending second, third, fourth, fifth and sixth placements. As Table 4 shows, they accounted for over half (57\%) of first placement endings, and never less than $30 \%$, whatever the sequential order. They also persistently accounted for a higher percentage of endings than did disruptions and absconsions.

A small number of planned transitions (17:6\%) were agency-led moves, as children and young people moved to and from placements provided by other agencies such as the National Health Service or the criminal justice system. Others were purposive moves to progress care plans. For instance $46(15 \%)$ were moves to prospective adoptive placements and a further $32(11 \%)$ were to quasi-adoptive placements with relatives. However the majority of planned transitions (207: 69\%) were resource or practice-led, occasioned by a shortage of suitable placements, a lack of choice or inappropriate planning. These included moves to reunite sibling groups who had initially been separated, moves to more appropriately match children to carers of the same ethnicity and culture, moves to and from temporary placements when foster carers went on holiday, and moves from a short-term to a longer-term foster placement once it became clear that a child could not return home quickly. 


\section{Precipitate moves: disruptions and absconscions}

Only a relatively small proportion of placements (145: $21 \%)$ in this study disrupted at the carer's request, although a substantial number of other moves (101:14\%) were initiated in an attempt to preserve a placement, by offering carers temporary respite care in the hope that they would be able to continue to meet a child's exceptional needs with additional support.

Other precipitate moves (76:11\%) were initiated by children and young people who refused to stay in placements where they were unhappy, sometimes precipitating one change by absconding and then another on their reappearance. All children and young people who absconded also experienced the disruption of at least one placement at the request of carers, and almost half (44\%) of the 86 children who experienced one disruption went on to experience another, twenty of them experiencing three or more. Placements with relatives (45\%) or with parents (40\%) were more likely to disrupt than those with foster carers (24\%), in residential units (28\%) or in independent living. No children absconded from placements with parents or relatives; almost all absconscions were from residential placements.

As Figure 2 demonstrates, although the placements of children who displayed emotional or behavioural difficulties or committed offences were significantly more likely to disrupt (at the carer or child's request or through absconscion) than those of children who showed no evidence of additional support needs, 38 (17\%) of placements for this latter group ended in breakdown. Twenty of these were for children aged under three. 


\section{INSERT FIGURE 2 HERE}

\section{Discussion}

\section{The context of placement changes}

These findings point to a number of questions that need to be explored further if we are to improve both the quality of care that children receive and also their chances of achieving successful outcomes. In the following discussion qualitative data from interviews with the children and young people concerned are used to illustrate some of the key issues.

Changes of placement need to be understood within the context of a care system which is characterised by instability. Changes of social worker are built into the system as responsibility for a child or young person moves from the referral and assessment team to one that caters for children in care and then perhaps again to one that provides a specialist service for children placed for adoption or for older care leavers. Among practitioners, annual turnover rates are also high, averaging around 12\% between 2001 and 2005, and these are compounded by large numbers of staff recruited on short-term agency contracts to fill the high vacancy rates (Department for Education and Skills and Department of Health, 2006). Forty (17\%) of the children and young people in the sample experienced four or more changes of social worker during the three or four years they were studied.

Furthermore the pattern of constant change is reinforced by the experience of transience within as well as between placements. In some foster homes and, more 
particularly in residential units, children are constantly moving in and out; seeing others entering and leaving a placement can be stressful for those who remain:

“There's so many kids coming in and out of children's homes or foster homes. You can have a best friend one day, and then, you can go to the shop and they're not allowed to tell you where they've gone, so you don't know."

(Joanne. Age at entry: 14 years. Age left: 16 years old)

The children and young people themselves were well aware of the unsettling effects of constant change::

"I used to hate it when I either had to change social workers or change placements or something like that because it was just another thing to get used to....just settling into new families and starting all over again....fitting in with other kids that live there especially if it was their birth children....it varied how they treated you, especially when they compared you to their own, and when they got annoyed with you because you didn't know how to take them or anything."

(Eliza. Age at entry: 12 years. Age left:13 years old.)

In the words of one of the adoptive parents:

"From the experience that I've had adopting three children with special needs, all different backgrounds, different circumstances, for adoptions, I would like to say that...children do not bounce. Yes, they are resilient, but if you move a child several times before its adoption then the adoptive parents are going to have a very long 
struggle to get them to realise that this is where they are for good, this is where you're going to stay... because children will be very hesitant to give you their love, to trust you..... If a child's got special needs and they've been moved several times, it does take years for them to settle down" (Adoptive parent of Harry. Age at entry under one. Age left: 2 years old.)

Older children must find it very difficult to think about the future, to settle down to work at school, or to make friends if they are uncertain where they will be living in the next school term. Moreover, while changes of placement may, in themselves, be unsettling, they are often accompanied by other changes which compound the experience of instability. A change of placement often also entails a change of school (see Social Exclusion Unit, 2003), although there is evidence that some authorities in this study made efforts to prevent this (Skuse and Ward, 2003). Changing placements can also impact on health care, as when children and young people move it can take months for records to be transferred and for new appointments to be made - a key issue for a population such as this one, with extensive health and mental health care needs (see Ward et al., 2002).

Moreover the pattern of instability found in care frequently mirrored children and young people's experiences before and after the care episode. The life histories of the 42 infants in the sample revealed frequent changes of address, domicile and carer before they entered care, even though they did so before their first birthdays. In the few months they had lived with their birth families, eleven of these babies had had four or more addresses, 18 had had at least two primary carers and five had had four or more (see Ward, Munro and Dearden, 2006). The interviews with the young 
people who had been reunited with their families on leaving care demonstrated how, for some, this pattern of instability had continued throughout their childhood:

'Well my Dad took me to live with him and my stepmother and then after two weeks he gave me to my Granny and he said 'Here, you have him, I don't want him', and then after a week he came down and took me to my Nana's and then after six weeks I was at my Dad's .... and then after four days I was living with my Auntie for three weeks and then I started living with my Nana again' (Gary, age at entry 9 years. Age left: 12 years old)

For this young man, as well as for other young people interviewed, changes of domicile within his birth family were also accompanied by a disrupted education.

\section{Disruptions and managed moves}

There is therefore no doubt that children in care change placements too frequently. Moves within the care system are often part of a pattern of instability experienced both within the birth family home and while looked after by the local authority and therefore reinforce many children's perceptions of a life that is characterised by transience.

Disrupted placements that break down when carers can no longer cope can be damaging to all concerned, and much of the literature focuses on the relationship between children's challenging behaviour patterns and instability of care (see Chamberlain et al., 2006; James et al., 2004). The qualitative data showed that, while some children had extensive emotional and behavioural difficulties, some foster 
carers and, more particularly, residential workers also lacked sufficient training or skills to cope with problems when they arose (Skuse and Ward, 2003). Evidence from both this and other studies indicates that placements with relatives and parents may be particularly liable to break down because they receive insufficient financial, practical or emotional support to meet the needs of children in often very difficult situations (Ward, Holmes and Soper, 2008; Hunt, Waterhouse and Lutman, 2008).

However disruptions are by no means the most frequent reason why placements end. As we have seen, in England the most common moves occur as planned transitions, embedded within the case management process. A high proportion of children who enter care are already well known to children's social services, yet most admissions are known to be precipitate and unplanned, although routine data on this issue are not collected. Spiralling costs of care and a shortage of suitable placements have meant that the decision to admit is often put off until a crisis forces the issue (see Packman and Hall, 1998). The first (emergency) placement may then be deemed only a stop-gap solution, necessitating a subsequent move. Such movement is compounded by shortages of specialist placements, particularly for large sibling groups or for black and minority ethnic children, who may initially be placed inappropriately and then move to be with siblings or with carers with whom they are better matched. While many of these are positive moves, they may follow a period spent in limbo where few long-term plans can be made. Other planned moves are perhaps less positive, occurring at the end of an intensive treatment placement, and designed both to help the child move on to something less structured and to free up an expensive resource for someone else. Some children will inevitably view such a move as yet another disruption in an already disrupted life. Although planned endings 
may be less devastating than the breakdown of a placement for all concerned, frequent changes, whatever their cause, are not without cost.

To some extent instability in care is a consequence of the presumption enshrined in both law and practice that most children are best off living with their birth families. This means that, when children are placed in out-of-home care, care plans are often temporary, and made with the expectation of a swift return home. An analysis of the initial care plans of this sample of 242 children who subsequently remained in care for a year or more showed that at entry $51(22 \%)$ were expected to remain with their birth families or return within six months, and a further 76 (33\%) were admitted for assessment only. Many of these children would have been placed with short-term carers, and have then had to move when it became evident that they required longer placements. The finding from this and from another recent study of the English care system (Sinclair et al., 2008), that patterns of movement for populations of children in care do not show a significant decrease until the third year after entry, reflect the assumption that care will almost always be a temporary phase until the parents' difficulties are resolved, rather than a long term solution. Yet the latest statistics show that $50 \%$ of care episodes last for at least one year and 15\% for at least five (Department for Children, Schools and Families, 2008b).

While the principle that children are best brought up by their birth families is obviously correct both in terms of human rights and child development, it leads to a culture that makes it difficult for professionals to acknowledge that some parents will not be able to overcome their difficulties sufficiently to resume care of their children within a realistic timescale (Ward, Munro and Dearden, 2006). This is true not only of social 
work professionals but also the courts. The in-depth study of very young children who formed part of this sample showed that a number of placements with parents disrupted as part of the process by which a decision to place for adoption was reached. These placements were often made against the advice of social workers, but at the direction of courts on the grounds that there was insufficient evidence of parents' incapacity for permanent separation to be approved (Ward, Munro and Dearden, 2006). Almost half of the disrupted placements with parents or relatives were for young children aged under four at the start of the care episode and this may have been a major reason for their precipitate endings in the sample as a whole.

Decision-making in child welfare is often a process of carefully balancing the conflicting interests of parent and child, thrown into sharper focus in England by the incorporation of the European Convention on Human Rights into British law. Article 8 of the Convention enshrines a right to 'respect for private and family life', which may come into conflict with Article 3 which declares that 'no one shall be subject to .... inhuman or degrading treatment or punishment' (see Munro and Ward, 2008 for further details). An unlooked for consequence may be that, as we attempt to ensure that parents' rights are properly respected, we subject their children to months of instability and uncertainty which can then compromise their life chances.

\section{Conclusion}

The data from this study demonstrate the nature of instability in the English care system. While there are differences in the number and type of moves experienced by children and young people of different age groups and displaying different patterns of 
need, changes of placement have many causes and may be experienced by any child or young person who enters care.

Since these data were collected, national policy initiatives to improve outcomes for children in care have attempted to address this issue in England (Department for Education and Skills, 2001; 2004; 2007). However the most recent figures show that although there has been some positive change over the last five years, instability is still extensive and difficult to reduce (Department for Children, Schools and Families, 2008b). As this study shows, effective strategies to increase the stability of care need to address not only placement disruptions but also the prevalence of planned transitions embedded in the system, and their numerous causes. This means addressing not only the resource issues that lead to a shortage of suitable provision, but also the practice issues that delay decision-making, leading to precipitate entries and long periods in unstable temporary placements that compound children's perceptions of transience and jeopardise their chances of achieving long-term wellbeing. 


\section{References}

Darker, I., Ward, H., \& Caulfield, L. (2008). An analysis of offending by young people looked after by local authorities. Youth Justice, 8, (2), 138-148.

Department for Children, Schools \& Families (2008a). Outcome Indicators for Children Looked After: Twelve months to 30 September 2007, England. London: Department for Children, Schools \& Families.

Department for Children Schools \& Families (2008b). Children Looked After in England (Including Adoption and Care Leavers: year ending 31 March 2007 (SFR27/2007). London: Department for Children, Schools \& Families

Department for Education \& Skills (2007). Care Matters: Time for Change. White Paper, Cm.7137. London: The Stationery Office.

Department for Education \& Skills (2003). Every Child Matters. Green Paper, Cm.5860. London: The Stationery Office.

Department for Education \& Skills (2001) Planning and Providing Good Quality Placements for Children in Care. London: Department for Education \& Skills.

Department for Education \& Skills and Department of Health (2006). Options for Excellence: Building the social care workforce of the future. London: Department of Health. 
Hunt, J., Waterhouse, S., and Lutman, E. (2008). Keeping Them in the Family: Outcomes for children placed in kinship care through care proceedings. London: British Association for Adoption and Fostering.

Meltzer, H., Gatward, R., Corbin, T., Goodman, R., \& Ford, T. (2003). The Mental Health of Young People Looked After by Local Authorities in England. London: The Stationery Office.

Moyers, S., \& Mason, A. (1995). Identifying standards of parenting. In Ward, H. (Ed.), Looking after children: Research into practice. London: The Stationery Office.

Munro, E.R. and Ward, H. (2008). Balancing parents' and very young children's rights in care proceedings : decision-making in the context of the Human Rights Act 1998 . Child and Family Social Work, 13 (2), 227-234

Packman, J., and Hall, C. (1998). From Care to Accommodation: Support, Protection and Control in Child Care Services. London: The Stationery Office.

Richardson, J., \& Joughin, C. (2000). The Mental Health Needs of Looked After Children. London: Gaskell.

Rowe, J., Hundleby, M., \& Garnett, L. (1989). Child Care Now: A survey of Placement Patterns. London: British Agencies for Adoption and Fostering. 
Social Exclusion Unit (2003). A Better Education for Children in Care. London: The Stationery Office

Sergeant, H. (2006). Handle with Care. London: Centre for Policy Studies.

Stein, M., \& Munro, E. R. (Eds.). (2008). Young People's Transitions from Care to Adulthood: International Research and Practice. London: Jessica Kingsley Publishers.

Sempik, J., Ward, H., \& Darker, I. (2008). Emotional and behavioural difficulties of children and young people at entry to care. Clinical Child Psychology and Psychiatry, $13(2), 221-233$

Sinclair, I., Baker, C., Lee, J., \& Gibbs, I. (2007). The Pursuit of Permanence: A Study of the English Care System. London: Jessica Kingsley Publishers.

Skuse, T., Macdonald, I., \& Ward, H. (2000). Outcomes for Looked After Children: The Longitudinal Study at the Third Data Collection Point (30.9.99), Loughborough: Loughborough University.

Skuse, T., \& Ward, H. (2003). Outcomes for Looked After Children: Children's Views of Care and Accommodation. Interim report to the Department of Health. Loughborough: Centre for Child and Family Research. 
Unrau, Y. A. (2007). Research on placement moves: Seeking the perspective of foster children. Children and Youth Services Review, 29, (1), 122-137.

Unrau, Y. A., Seita, J. R., \& Putney, K. S. (2008). Former foster youth remember multiple placement moves: A journey of loss and hope. Children and Youth Services Review, 30, (11), 1256-1266.

Ward, H. (2008). Enfants Placés en Angleterre : Est-qu'ils Profitent d'être Separés de Leurs Familles ou non ? Paper presented at Ensemble : Le Congres de l'Association des Centres Jeunesse du Quebec, November 2008

Ward, H., Jones, H., Lynch, M. \& Skuse,T. (2002).Issues concerning the health of looked after children. Adoption and Fostering, 26 (4), 1-11

Ward, H., Munro, E.R., \& Dearden, C. (2006). Babies and Young Children in Care: Life Pathways, Decision-making and Practice. London: Jessica Kingsley Publishers.

Ward, H., Holmes, L., \& Soper, J. (2008). Costs and Consequences of Placing Children in Care. London: Jessica Kingsley Publishers.

Ward, H., \& Holmes, L. (2008). Calculating the costs of local authority care for children with contrasting needs. Child and Family Social Work, 13, (1), 80-90. 
Figure 1: Children's ages at entry to care or accommodation $(n=242)$

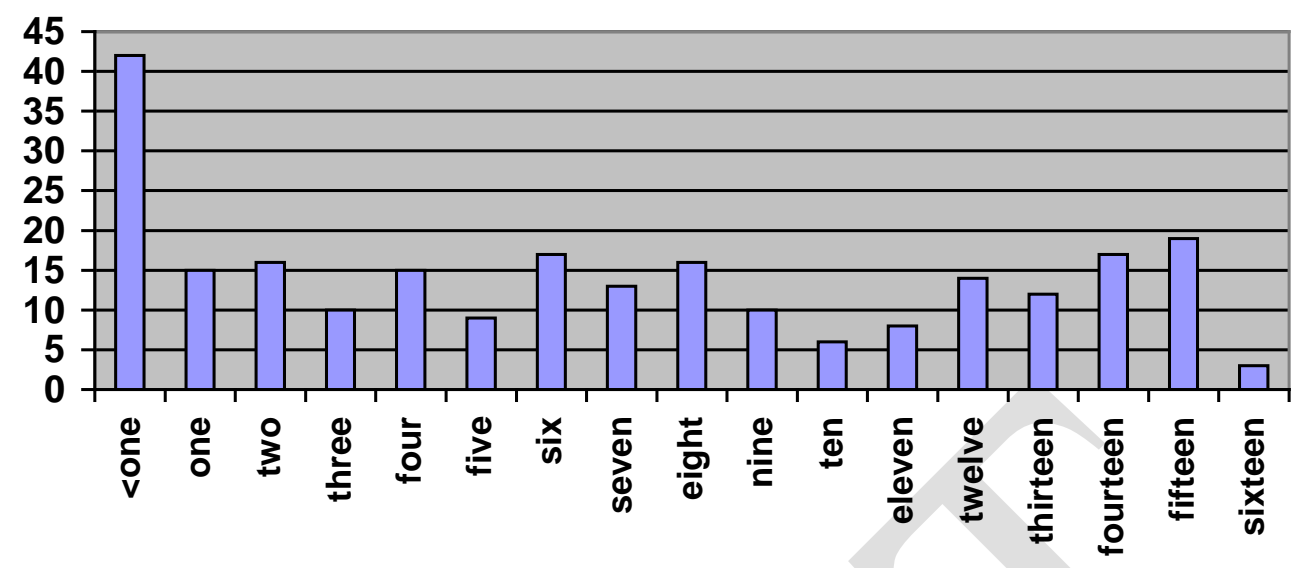

$\square$ ages at entry 
Figure 2: Reasons for moves by needs groups

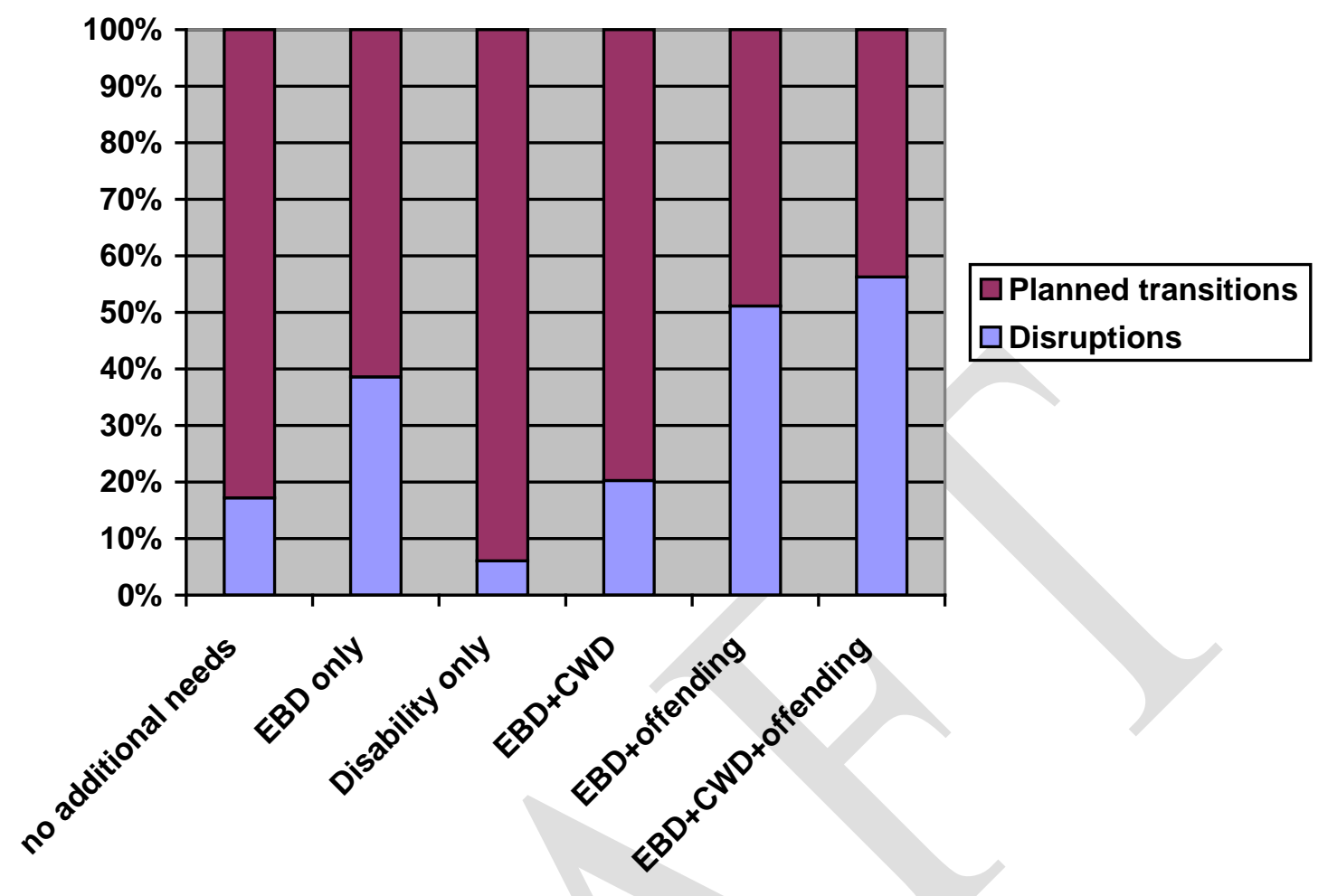


Table 1: Sample children grouped according to needs $(n=242)$

\begin{tabular}{|l|l|l|}
\hline & Frequency & Percent \\
\hline No additional needs & 95 & 39 \\
\hline EBD* only & 49 & 20 \\
\hline Disability only & 23 & 10 \\
\hline EBD plus disability & 56 & 23 \\
\hline EBD plus convictions & 15 & 6 \\
\hline $\begin{array}{l}\text { EBD plus convictions } \\
\text { plus disability }\end{array}$ & 4 & 2 \\
\hline TOTAL & 242 & 100 \\
\hline
\end{tabular}

* Emotional and/or behavioural difficulty 
Table 2: Age group by total number of placements $(n=242)$

\begin{tabular}{|c|c|c|c|c|c|c|}
\hline & $\begin{array}{l}1 \\
\text { placement }\end{array}$ & $\begin{array}{l}2 \\
\text { placements }\end{array}$ & $\begin{array}{l}\text { 3-5 } \\
\text { placements }\end{array}$ & $\begin{array}{l}6-9 \\
\text { placements }\end{array}$ & $\begin{array}{l}10+ \\
\text { placements }\end{array}$ & total \\
\hline $\begin{array}{l}0-4 \\
\text { years }\end{array}$ & $10(10 \%)$ & $27(28 \%)$ & $44(45 \%)$ & $16(16 \%)$ & $1(1 \%)$ & $98(100 \%)$ \\
\hline $\begin{array}{l}5-9 \\
\text { years }\end{array}$ & $12(19 \%)$ & $15(23 \%)$ & $26(40 \%)$ & $12(1$ & 0 & $65(100 \%)$ \\
\hline $\begin{array}{l}10+ \\
\text { years }\end{array}$ & $24(30 \%)$ & $12(15 \%)$ & $19(24 \%)$ & $15(19 \%)$ & $9(12 \%)$ & $79(100 \%)$ \\
\hline Total & $46(19 \%)$ & $54(22 \%)$ & $89(37 \%)$ & $43(18 \%)$ & $10(4 \%)$ & $242(100 \%)$ \\
\hline
\end{tabular}


Table 3: Reasons for moves within the care system $(n=700)$

\begin{tabular}{|c|c|c|}
\hline Reason for leaving & Frequency & Percent \\
\hline \multicolumn{3}{|l|}{ Moves initiated by carers } \\
\hline Carer requested disruption & 145 & 21 \\
\hline Foster carer required relief & 52 & 7 \\
\hline Return from relief placement & 49 & 7 \\
\hline \multicolumn{3}{|l|}{$\begin{array}{l}\text { Moves initiated by child/you } \\
\text { person }\end{array}$} \\
\hline Child requested disruption & 33 & 5 \\
\hline Child absconded & 23 & 3 \\
\hline Return from absconding & 20 & 3 \\
\hline \multicolumn{3}{|l|}{ Moves initiated by local authority } \\
\hline $\begin{array}{l}\text { Planned transition to new } \\
\text { placement }\end{array}$ & 302 & 43 \\
\hline Placement no longer available & 76 & 11 \\
\hline Total moves within care system & 700 & 100 \\
\hline $\begin{array}{l}\text { Moves out of care (child ceased to } \\
\text { be looked after) }\end{array}$ & 125 & \\
\hline Missing /no information & 18 & \\
\hline Total moves & 843 & \\
\hline
\end{tabular}


Table 4: Percentage of placements ending in planned transition or disruption, shown sequentially

\begin{tabular}{|l|l|l|l|}
\hline Placement & Number of & $\begin{array}{l}\text { \% ending in } \\
\text { planned } \\
\text { transitions to } \\
\text { another } \\
\text { placements }\end{array}$ & $\begin{array}{l}\text { \% ending in } \\
\text { disruption or } \\
\text { absconsion }\end{array}$ \\
\hline $\mathbf{1}^{\text {st }}$ & 242 & $57 \%$ & $15 \%$ \\
\hline $\mathbf{2}^{\text {nd }}$ & 197 & $37 \%$ & $19 \%$ \\
\hline $\mathbf{3}^{\text {rd }}$ & 142 & $31 \%$ & $20 \%$ \\
\hline $\mathbf{4}^{\text {th }}$ & 97 & $30 \%$ & $19 \%$ \\
\hline $\mathbf{6}^{\text {th }}$ & 70 & $33 \%$ & $24 \%$ \\
\hline & 53 & $34 \%$ & \\
\hline & & & \\
\hline & & & \\
\hline & & & \\
\hline
\end{tabular}

